\title{
A probable case of movement disorder (Tardive dyskinesia) due to duloxetine treatment
}

\author{
Duloksetin tedavisine bağı beklenmedik bir hareket bozukluğu olgusu (Tardif diskinezi)
}

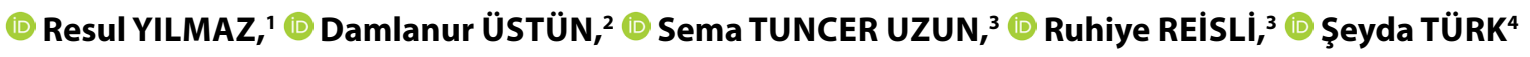

\begin{abstract}
Summary
Tardive dyskinesia and tardive dystonia are caused by dopamine receptor blocking agents, mostly antipsychotics and sometimes antidepressants or calcium channel blockers. Duloxetine is a serotonin-noradrenaline reuptake inhibitor used in the treatment of diabetic neuropathic pain and fibromyalgia, as well as major depression. In this case, we aimed to discuss the tardive dyskinesia-like appearance of a patient using duloxetine due to fibromyalgia.
\end{abstract}

Keywords: Duloxetine; fibromyalgia; tardive dyskinesia.

\begin{abstract}
Özet
Tardif diskineziye ve tardif distoniye, çoğunlukla dopamin reseptör bloke edici ajanlar, bazen de antidepresanlar veya kalsiyum kanal blokerleri neden olur. Duloksetin, diyabetik nöropatik ağrı ve fibromiyaljinin yanı sıra majör depresyon tedavisinde kullanılan bir serotonin-noradrenalin geri alım inhibitörüdür. Bu olguda fibromiyaljiye bağlı duloksetin kullanan bir hastanın tardif diskinezi benzeri görünümünü tartışmayı amaçladık.
\end{abstract}

Anahtar sözcükler: Duloksetin; fibromyalji; tardif diskinezi.

\section{Introduction}

Duloxetine is a serotonin-noradrenaline reuptake inhibitor used in the treatment of diabetic neuropathic pain and fibromyalgia, as well as major depression. ${ }^{[1]}$

The mechanisms of action of drugs are also responsible for their side effects. The most frequent side effects are nausea, dry mouth, dizziness, decreased appetite, constipation and insomnia. ${ }^{[1]}$

In this case report, we aimed to discuss the presentation of involuntary contraction following duloxetine use and possible tardive side effects.

\section{Case Report}

A 60-year-old male presented with occasionally exacerbated headache and sleep disturbance, for 30 years. According to the knowledge obtained from the patient's story, thepain was in his shoulders, neck and the back of his head, which spread to the top of the head. He stated that his pain gradually increased over time and for the last three months his pain continued constantly and that he had a sleep problem. He described his pain as throbbing and like a lighting strike. The patient also stated that his pain decreases slightly with massage and rest, but increases with movement, light and loud noise.

He had previously been examined in neurology and ear-nose-throat clinics, said he tried various treatments for pain, used analgesics and antibiotics, but none of themreduced the pain. The patient had no known systemic illness, he was found to have had acute rheumatic fever in his childhood, but had no residual effecton his follow-up. Physical examina-

\footnotetext{
'Department of Anesthesiology and Reanimation, Zile State Hospital, Tokat, Turkey

${ }^{2}$ Department of Anesthesiology and Reanimation, Turhal State Hospital, Tokat, Turkey

${ }^{3}$ Department of Anesthesiology and Reanimation, Necmettin Erbakan University Meram Faculty of Medicine, Konya, Turkey

${ }^{4}$ Department of Anesthesiology and Reanimation, Beyhekim State Hospital, Konya, Turkey

Submitted: 19.11.2017 Accepted after revision: 02.01.2018 Available online date: 25.10.2018

Correspondence: Dr. Resul Yılmaz. Zile Devlet Hastanesi, Anesteziyoloji ve Reanimasyon Bölümü, Zile, Tokat, Turkey.

Phone: +90 - 544 - 9005580 e-mail: dr.r.yilmaz@gmail.com

(C) 2018 Turkish Society of Algology
} 
tionrevealed normal examination findings except forpainful neck movements and trigger points in the neck, which were sensitive to touch.

The patient was diagnosed with fibromyalgia and his pain was evaluated as neuropathic pain. Duloxetine (30 mg/day)and dexketoprofen ( $25 \mathrm{mg}$, to be used when the pain intensified) was prescribed. We suggested to keep apain diary and come to a follow-up after 10 days.

When the patient arrived 10 days later, he stated that his pain decreased significantly. However, he described spazm in the temporamandibular joint and muscles, that began 3-4 days ago. He stated that this spazm starts approximately 5 hours after taking his medication and it lasts for about 4 hours. The physical examination didn't show any pathologic findings. But it should be kept in mind that he didn't have any symptoms at the time of the examination. Based on the patient's expressions, these complaints were thought to be related to tardive dyskinesia. Termination of the treatment was suggested but despite this side effect, the patient didn't want to discontinue his medication and he didn't accept any other treatment. The treatment was continued by recommending caution against movement disorders.

The patient didn't come for a follow-up after that. About a month later we contacted him by phone and he informed us that he used the medication for 10-15 days butdid not continue to do so after the headache was fully relieved, and that his jaw contractions disappeared completely.

\section{Discussion}

Tardive dyskinesia and tardive dystonia are caused by dopamine receptor blocking agents, mostly antipsychotics and sometimes antidepressants or calcium channel blockers. ${ }^{[2]}$ Duloxetine-associated tardive syndrome is rarely reported in the literature.

While pathophysiological basis of tardive dystonia is still uncertain, the current model is the hypersensitivity of postsynaptic dopamine-2 (D2) receptors in the nigrostriatal dopamine pathway resulting from prolonged inhibition of receptors. According to this theory, the long-term administration of dopamine receptor blocker causes denervation supersensitiv- ity and upregulation of these receptors. As a result, there is an increased availability of postsynaptic D2 receptors to interact with endogenous dopamine and this leads to a hyperkinetic motor condition known as tardive dyskinesia. ${ }^{[3]}$

Serotonergic and noradrenergic modulation of cholinergic pathways has also been suggested to play a role in the formation of tardive dystonia. ${ }^{[4]}$ In another theory, while D2 receptor blockade is present, repeated stimulation of $D 1$ receptor by endogenous dopamine causes D1-mediated striatal pathway sensitization and dystonia. ${ }^{[5]}$

Neurophysiological and electrical studies have shown that serotonin released by the raphe nucleus inhibits striatal neurons. ${ }^{[6]}$ Thus, the inhibition of neuronal serotonin reuptake by increasing the presence of serotonin may produce a similar therapeutic effect to dopamine blocking agents. This hypothesis potentially explains the movement disorders that may result from antidepressants. Preclinical researches have shown that duloxetine inhibits neuronal serotonin and norepinephrine reuptake. Increased serotonin transit may also result in inhibition of dopaminergic neurotransmission, which may contribute to tardive dyskinesia and tardive dystonia. ${ }^{[6]}$

Tricyclic antidepressants, fluoxetine, paroxetine, venlafaxine, trazodone, valbenazine, antipsychotics, can cause tardive dyskinesia. ${ }^{[7-13]}$ There are a few case reports of duloxetine-related dystonia reported, and the symptom in one of these patients is mandibular muscle contraction. ${ }^{[14,15]}$

In our patient, the facts that the symptoms first began within 3-4 days after the initiation of duloxetine treatment and that they start approximately 5 hours after taking his medication suggest dystonia. Because of this, termination of the treatment was planned.

While there is no definitive treatment for tardive dyskinesia, tetrabenazine is the most effective choice. Vitamin B6, vitamin E, donepezil, levetiracetam and botulinum toxin are other treatment options. In more serious cases, surgical intervention and deep brain stimulation may be the treatment option, but further research is needed. ${ }^{[16]}$ 


\section{Conclusion}

Tardive dyskinesia and tardive dystonia are caused by dopamine receptor blocking agents, mostly antipsychotics and sometimes antidepressants or calcium channel blockers. To our knowledge, there is only two report of tardive dyskinesia and tardive dystonia during treatment with duloxetine. Although these medications have a lower risk of causing tardive syndrome, clinicians should be cautious for involuntary movement during duloxetine treatment.

\section{Informed Consent: Written informed consent was obtained from the patient who participated in this study.}

\section{Conflict-of-interest issues regarding the author- ship or article: None declared.}

\section{Peer-rewiew: Externally peer-reviewed.}

\section{References}

1. Trivedi MH, Desaiah D, Ossanna MJ, Pritchett $Y L$, Brannan SK, Detke MJ. Clinical evidence for serotonin and norepinephrine reuptake inhibition of duloxetine. Int Clin Psychopharmacol 2008;23(3):161-9. [CrossRef]

2. Jankovic J. Tardive syndromes and other drug-induced movement disorders. Clin Neuropharmacol 1995;18(3):197-214. [CrossRef]

3. Çavuşoğlu H. Bazal ganglionlar-Motor fonksiyonları. In: Guyton AC, Hall JE, editors. Tıbbi Fizyoloji. 9th ed. İstanbul: Alemdar; 1996. p. 728.

4. Remington GJ. The Pisa syndrome: possible role for se- rotonin and noradrenaline. J Clin Psychopharmacol 1988;8(3):228-9. [CrossRef]

5. Trugman JM, Leadbetter R, Zalis ME, Burgdorf RO, Wooten GF. Treatment of severe axial tardive dystonia with clozapine: case report and hypothesis. Mov Disord 1994;9(4):441-6.

6. Leo RJ. Movement disorders associated with the serotonin selective reuptake inhibitors. J Clin Psychiatry 1996;57(10):449-54. [CrossRef]

7. Yassa R, Camille Y, Belzile L. Tardive dyskinesia in the course of antidepressant therapy: a prevalence study and review of the literature. J Clin Psychopharmacol 1987;7(4):243-6.

8. Clayton AH. Antidepressant-induced tardive dyskinesia: review and case report. Psychopharmacol Bull 1995;31(2):259-64.

9. Dubovsky SL, Thomas M. Tardive dyskinesia associated with fluoxetine. Psychiatr Serv 1996;47(9):991-3. [CrossRef]

10. Boffa E, Lofchy J. Paroxetine and tardive akathisia. Can J Psychiatry 2000;45(2):196.

11. Botsaris SD, Sypek JM. Paroxetine and tardive dyskinesia. J Clin Psychopharmacol 1996;16(3):258-9. [CrossRef]

12. Lee Y, Yeh WC, Chong MY, Lin PY, Chang YY. Venlafaxine and tardive blepharospasm: a case report. Prog Neuropsychopharmacol Biol Psychiatry 2007;31(5):1139-40. [CrossRef]

13. L Lin CC, Lin PY, Lee Y, Chang YY, Chen CH. Tardive dystonia and tardive sensory syndrome related to trazodone: a case report. Prog Neuropsychopharmacol Biol Psychiatry 2008;32(6):1609-10. [CrossRef]

14. Deuschle $M$, Mase $E$, Zink M. Dyskinesia during treatment with duloxetine. Pharmacopsychiatry 2006;39(6):237-8.

15. Chen PY, Lin PY, Tien SC, Chang YY, Lee Y. Duloxetine-related tardive dystonia and tardive dyskinesia: a case report. Gen Hosp Psychiatry 2010;32(6):646.e9-11 [CrossRef]

16. Kenney C, Hunter C, Davidson A, Joseph J. Metoclopramide, an increasingly recognized cause of tardive dyskinesia. J Clin Pharmacol 2008;48(3):379-84. [CrossRef] 